UDC $613 ; 614$

DOI: 10.21668/health.risk/2020.4.07.eng

Research article

\title{
EMERGENCE AND VARIABILITY OF INFLUENCE EXERTED BY WEATHER AND CLIMATIC FACTORS ON LIFE EXPECTANCY IN THE RUSSIAN FEDERATION TAKING INTO ACCOUNT DIFFERENTIATION OF RF REGIONS AS PER SOCIOECONOMIC AND SANITARY-EPIDEMIOLOGIC DETERMINANTS
}

\author{
N.V. Zaitseva ${ }^{1}$, S.V. Kleyn ${ }^{1}$, D.A. Kiryanov ${ }^{1,2}$, M.V. Glukhikh ${ }^{1}$, M.R. Kamaltdinov ${ }^{1}$ \\ ${ }^{1}$ Federal Scientific Center for Medical and Preventive Health Risk Management Technologies, \\ 82 Monastyrskaya Str., Perm, 614045, Russian Federation \\ ${ }^{2}$ Perm State National University, 15 Bukireva Str., Perm, 614990, Russian Federation
}

The present research focuses on estimating influence exerted by weather and climatic factors on life expectancy (LE) in the Russian Federation taking into account socioeconomic and sanitary-epidemiologic determinants. To estimate influence exerted by this factor on LE, a mathematic model was applied; the model was based on neuron networks and allowed taking into account emergence and variability of influence exerted on changes in LE by a set of heterogeneous factors including weather and climatic ones.

It was established that over 2010-2018 climate changed in most RF regions as there was a growth in average monthly temperatures (temperature deviated from its long-term average monthly values by $+1.2{ }^{\circ} \mathrm{C}$ in July, and by $+1,5^{\circ} \mathrm{C}$ in January), and changes in precipitations (deviations amounted to $-1.9 \%$ in July and $+13.0 \%$ in January). It was established that «average monthly temperature in July» exerted the greatest direct influence on LE; thus, if this parameter grows by $1 \%$, it results in additional 1.7 days of $L E$.

"Average precipitations quantity in January» turned out to be the most significant factor leading to a decrease in LE; a $1 \%$ growth in this parameter resulted in LE decrease by 0.12 days. It was shown that mathematical expectancy of LE loss variability in RF regions obtained basing on 85 scenarios of weather and climatic conditions ranged from -4.2 days to 348.7 days. Overall in the RF climate-associated losses in LE taken as weighted average as per population number amounted to 191.7 days. It was established that climate-associated losses in LE were authentically lower in North Caucasian regions than in regions located in temperate zone with Atlantic-continental and continental climate (by 1.6 and 1.8 times accordingly). We also comparatively analyzed losses in LE due to influence exerted by climate in RF regions distributed into different groups (clusters) as per socioeconomic parameters; the analysis revealed authentic differences between the second and the fourth cluster $(p=0.01)$, and between the third and the fourth ones $(p=0.006)$. We didn't reveal any authentic differences in climate-associated losses in LE among clusters as per sanitary-epidemiologic parameters.

Key words: life expectancy, climate, weather-climatic factor, global climatic change, artificial neuron networks, factor analysis, $R F$ population, demographic policy in the RF.

(C) Zaitseva N.V., Kleyn S.V., Kiryanov D.A., Glukhikh M.V., Kamaltdinov M.R., 2020

Nina V. Zaitseva - Academician of the Russian Academy of Sciences, Doctor of Medical Sciences, Professor, Scientific Director (e-mail: znv@fcrisk.ru; tel.: +7 (342) 237-25-34; ORCID: https://orcid.org/0000-0003-2356-1145).

Svetlana V. Kleyn - Doctor of Medical Sciences, Associate Professor, Head of the Department for Systemic Procedures of Sanitary-Hygienic Analysis and Monitoring (e-mail: kleyn@fcrisk.ru; tel.: +7 (342) 237-18-04; ORCID: https:// orcid.org/0000-0002-2534-5713).

Dmitrii A. Kiryanov - Candidate of Technical Sciences, Head of the Department for Mathematical Modeling of Systems and Processes; Associate Professor at Department for Human Ecology and Life Safety (e-mail: kda@fcrisk.ru; tel.: +7 (342) 237-18-04; ORCID: https://orcid.org/0000-0002-5406-4961).

Maksim V. Glukhikh - Post-graduate student, Junior researcher (e-mail: gluhih@fcrisk.ru; tel.: +7 (342) 237-18-04; ORCID: https://orcid.org/0000-0002-4755-8306).

Marat R. Kamaltdinov - Candidate of Physical and Mathematical Sciences, Senior researcher acting as the Head of the Department for Situation Modeling and Expert and Analytical Management Techniques Laboratory (e-mail: kmr@fcrisk.ru; tel.: +7 (342) 237-18-04; ORCID: http://orcid.org/0000-0003-0969-9252). 
Research on consequences that result from global climatic change performed worldwide and by Russian scientific experts as well highlights substantial influences exerted by this change on people's health. And publications tend to present a considerable number of facts confirming both direct and indirect, but predominantly negative, impacts exerted by these examined processes on human health.

Basic theses contained in reports issued by the Intergovernmental Panel on Climatic Change (IPCC) state that over a period slightly longer than 100 years global temperature has risen by approximately $1.0^{\circ} \mathrm{C}$; an increase in average sea level is caused by the World Ocean getting warmer and glaciers and snow melting; the latter also leads to depletion of drinking water resources. Experts believe a primary reason for global warming is worldwide increase in greenhouses gases emissions due to industrialization that is taking place in many countries; basic predictions for this century are limited to a temperature rise equal to $1.5-2.0^{\circ} \mathrm{C}[1,2]$.

The issue is vital for all countries in the world, including the RF; given that, in 2004 the country ratified the Kyoto Protocol and in 2016 the Paris Agreement was signed (has not yet come into force $)^{1,2,3}$ [3]. These international treaties are based on the United Nations Framework Convention on Climate Change with its primary goal being reduction in greenhouse gases emission as it will allow stabilizing the climatic system on the planet thus reducing overall health risks for the mankind ${ }^{4}$.

As for the Russian Federation, there is the Climatic doctrine in the national legislation with its primary goal being «...to provide safe and sustainable development of the RF including institutional, economic, ecological, and social, including demographic, aspects under changing climatic conditions.... ${ }^{5}$. Apart from the Climatic doctrine, there are several ecological projects that are now implemented in the RF and are aimed at finding solutions to issues related to climatic change. In particular, «Ecology» National project declares among its goals a $22 \%$ reduction in aggregated emissions volumes by 2024 in large industrial centers and it will allow minimizing health risks and reducing medical and demographic losses ${ }^{6}$.

According to the Report made by Rosgidromet on climatic risks existing on the RF territory climate in the country is warming significantly faster (by 2.5 times) than on average in the world; the process in the most intense in the Arctic and sub-Arctic zones in the RF. Apart from temperature growth in the ground atmosphere there is also change in quantity of precipitations, especially in winter and spring, in eastern and northern regions in the country where we can expect a significant increase in them in this century ${ }^{7}$.

The report also dwells on a growing threat related to hazardous weather and climatic phenomena that cause up to $90.0 \%$ of the most noticeable economic losses. According to statistic data provided by the document, a number of such phenomena grew considerably from $150-200$ in $1990-2000$ to $250-300$ in later years and this number tended to only grow. Floods, droughts, and other hazardous natural phenomena become more and more frequent, and moreover, their intensity grows resulting in even greater economic and demographic burden caused by climatic factors.

\footnotetext{
${ }^{1}$ The Paris Agreement. The United Nations Organization (UNO), 2015, 19 p.

2 The Kyoto Protocol to the United Nations Framework Convention on Climatic Change. The United Nations Organization (UNO), 1997. Available at: https://www.un.org/ru/documents/decl_conv/conventions/kyoto.shtml (30.09.2020) (in Russian).

${ }^{3}$ On ratifying The Kyoto Protocol to the United Nations Framework Convention on Climatic Change: The Federal Law issued on November 4, 2004 г. No. 128-FZ. Laws, codes, and regulatory acts in the Russian Federation, 2004. Available at: https://legalacts.ru/doc/federalnyi-zakon-ot-04112004-n-128-fz-o/ (30.09.2020) (in Russian).

${ }^{4}$ The United Nations Framework Convention on Climatic Change. The United Nations Organization (UNO), 1992. Available at: https://www.un.org/ru/documents/decl_conv/conventions/climate_framework_conv.shtml (30.09.2020) (in Russian).

${ }^{5}$ On the Climatic doctrine of the Russian Federation: The RF President Order issued on December 17, 2009 No. 861-rp. KonsultantPlus, 2009. Available at: http://www.consultant.ru/document/cons_doc_LAW_94992/(30.09.2020) (in Russian).

${ }^{6}$ The profile of «Ecology» National project. Approved by the Presidium of the RF Presidential Council on strategic development and national projects (The meeting report dated December 24, 2018 No. 16), 2018, 48 p. (in Russian).

${ }^{7}$ The report on climatic risks existing on the Russian Federation territory. Saint-Petersburg, 2017, 106 p. (in Russian).
} 
Besides, we can expect overall increase in heat waves duration with simultaneous fall in cold waves.

Conclusions on influence exerted by weather and climatic factors on people's health tend to be rather uncertain and allow only approximate estimates since most climate-related changes in the environment reflect only its indirect influence on human health. The only certainty here can be found regarding direct losses caused by natural disasters that result in thousands deaths annually as well as more intense phenomena such as heat waves that lead to an increase in number of deaths among people who suffer for cardiovascular and respiratory diseases, especially elderly people and urban population [4].

Indirect causes that result in increase in morbidity and mortality among population associated with weather and climatic factors include the following: a threat to food security (droughts, hail, and floods), growing areas where infectious agents are active and longer seasons when transmissible infections (malaria) can be caught, poorer drinking water quality and depletion of its reserves (diarrhea), climatic migration, etc [5]. This burden is going to be especially grave in developing countries where public healthcare systems will be unable to cope with the imminent danger. According to estimates made by the World Health Organization climatic changes occurring over 2030-2050 will raise an annual number of climate-related deaths up to 250 thousand, 38 thousand of them being due to impacts exerted by heat on susceptible population groups; 108 thousand, due to malaria and diarrhea; 95 thousand, due to hunger among children [4].

Conclusions made by experts are validated with results obtained via scientific research performed both in Russia and abroad and focusing on climatic change and related population health risks. Experts are starting to pay greater attention to impacts exerted by heat and cold waves on population mortality.
H. Achebak et al. accomplished a national examination in Spain and revealed that too high or too low temperatures created an elevated relative risk (RR) of deaths due to circulatory system diseases. The authors noted there were certain age and sex related peculiarities in such mortality; thus, women ran higher risks than men when the weather was hot and the same was true for people older than 90 against those aged 60-74 [6].

Research performed by M. Medina-Ramon and J. Schwartz involved examining a large sampling of cities in the US; the authors revealed that extreme temperatures (heat and cold) resulted in increased mortality due to myocardial infarction; and though mortality caused by respiratory diseases went down due to higher temperatures, this effect was negligible bearing in mind growing heat-related mortality caused by other diseases [7].

L. Zhang et al. state in their research work that there is a tight correlation between a socioeconomic situation existing on a specific territory where heat waves occur and an increase in morbidity among population, especially among elderly people [8]. Research performed in China revealed that heat waves resulted in losses on potential years of life $\left(\mathrm{YLL}^{8}\right)$, and it was true both for sub-tropical and moderatecontinental climatic zones. Besides, a cumulative effect produced by heat waves is higher than a single impact and it is much more apparent among elderly people $[9,10]$.

Several researchers state that an increase in mortality occurring against global climatic change will be due to not only weather and climatic factors but also related increase in ozone and particulate matter (PM) contents in ambient air [11-14]. There are also data on probable influence exerted by the climatic factor on life expectancy (LE) that indicate that LE has gone down by $0.12-0.39$ years on average in Europe, and some countries are expected to face a considerably greater decrease in LE [15].

B.A. Revich and D.A. Shaposhnikov focused on examining impacts exerted by popu-

\footnotetext{
${ }^{8}$ YLL - years of life lost (years of life lost due to untimely deaths).
} 
lation health on territories in the RF where climate was extremely continental. They revealed that there was an authentic increase in risks of elevated mortality due to all natural death causes, especially due to strokes caused by heat waves $(\mathrm{RR}=1.44$ for people older than 65). Impacts exerted by cold waves were less apparent but they were also characterized with authentic values $(\mathrm{RR}=1.11)$ [16]. Similar results were obtained for other weather-related criteria such as wind and cold index, efficient air temperature, and universal thermal climate index $^{9}$ [17].

Having generalized scientific data and experts opinions on impacts exerted by weather-climatic factors on population health, we can conclude that most of them indicate that there are wide-scale and sometimes even catastrophic effects related to increased mortality and, consequently, a decrease in life expectancy. But at the same time global warming that becomes apparent via average temperatures rising by $1-2{ }^{\circ} \mathrm{C}$ can make a climate in certain regions a bit milder; in its turn, it can cause a slight decrease in effects produced by extreme natural phenomena.

Experts from Rosgidromet are inclined to make similar conclusions; they state that «...there can be certain positive outcomes brought about by climate change in Russia; overall, one can mention better climatic conditions for agriculture, increase in water supply, and longer navigation along the Northern Sea Route. An existing trend for the heating season to become shorter and a rise in its average temperature (up to

$0.8^{\circ} \mathrm{C} / 10$ years in the central Yakutia) raises heat efficiency of buildings and constructions and creates conditions for reduction in energy consumption.... ${ }^{10}[18]$. Predicted improvements in various branches caused by climatic change can also become apparent via population health improvement and reduction in medical and demographic risks.

Since most $\mathrm{RF}$ regions are located in zones where climatic conditions are rather harsh, a direct transfer of most scientific conclusions is not substantiated, and the issue requires additional research. Moreover, scientific research practically never covers such tasks as assessing a contribution made by existing weather and climatic factors on population health taking into account socioeconomic, sanitary-epidemiologic, and other living conditions.

Our research goal was to assess emergence and variability of impacts exerted by weather and climatic factors on life expectancy in the Russian Federation taking into account socioeconomic and sanitary-epidemiologic conditions.

Data and methods. To assess impacts exerted by weather and climatic conditions on life expectancy among the RF population taking into account socioeconomic and sanitaryepidemiologic factors, we examined a system of cause-and-effect relations between parameters that described all the spheres and living conditions that were included into 6 groups (determinants): «public healthcare», «sanitaryepidemiologic welfare on a given territory», «economic situation», «socio-demographic parameters», «weather and climatic conditions on a given territory».

The examination involved applying system analysis procedures and relied on official statistical data provided by the Federal Statistic Service. Cause-and-effect relations were analyzed with a created mathematical model based on neural networks.

When creating the model, we took weather and climatic conditions as our initial (independent) parameters; apart from them we also took parameters that described socioeconomic and sanitary-epidemiologic situa-

\footnotetext{
${ }^{9}$ Shartova N.V., Shaposhnikov D.A., Konstantinov P.I., Revich B.A. Universal thermal climate index applied to determine thresholds of temperature-related mortality. Health Risk Analysis, 2019, no. 3, pp. 83-93. DOI: 10.21668/health.risk/2019.3.10.eng

${ }^{10}$ The second estimate report made by Rosgidromet on climate change and its outcomes on the RF territory. Section 6 . Impacts exerted by climate change on economic entities and population health. Ways to adapt to these impacts. Moscow, Federal Service for Hydrometeorology and Environmental Monitoring Publ., 2014, pp. 43-56. (in Russian).
} 
tion as well as parameters related to lifestyle that were examined in detail in previous research works ${ }^{11,12}$. Average monthly temperatures and precipitations quantity in July and January were taken as weather and climatic conditions as well as their deviations from average long-term values in a given RF region over $2010-2018^{13}$. Life expectancy in $\mathrm{RF}$ regions was a dependent variable in our model and was estimated basing on data provided by the Federal State Statistic Service over 2010-2018 ${ }^{14}$.

We modeled cause-and-effect relations basing on all the collected data that reflected spatial and time distribution of all the examined parameters. As there were too many variables included into the model and multiple internal correlations, we reduced initial data dimensions via factor analysis; as a result, our initial scheme that included 148 parameters (socioeconomic, sanitary-epidemiologic, and weather and climatic ones) was transformed into one containing 33 common factors.

Cause-and-effect relations were modeled basing on creating a neural network model that took into account multiple and non-linear relationships between separate parameters. The neural network was trained basing on common factors values calculated for each RF region and LE parameter.

We applied the trained neural network model for cause-and-effect relations that showed impacts exerted by a set of parameters on life expectancy to solve two analytical tasks; the first one was to assess parameters as per intensity of their impacts exerted on LE; the second task was to assess a contribution made by existing weather and climatic conditions into loss of LE years.

To solve the first task, we made model calculations of changes in life expectancy un- der sequential $1 \%$ increase in each analyzed parameter in comparison with average country levels. This examination allowed obtaining averaged comparative assessments of changes in life expectancy for each parameter that were used as a criterion for ranking.

A contribution made by weather and climatic factors into life expectancy was determined basing on series of numerical experiments that reflected probable changes in LE in RF regions in case of changes in independent variables. To do that, we sent signals on the input layer in the neural network that were actual and scenario values of sanitary-epidemiologic, socioeconomic, and weather and climatic conditions transformed into common factors via factor analysis. Difference in predicted LE values calculated with scenario and actual values of variables was used as a measure for probable changes in life expectancy associated with changes in the examined factors (1):

$$
\Delta L E_{j}^{k}=F\left(\widetilde{X}_{j}^{k}\right)-F\left(\widetilde{X}_{j}^{0}\right),
$$

where $\Delta L E_{j}^{k}$ is a change in life expectancy in $j$-th RF region under $k$-th scenario impacts exerted by factors, days;

$F\left(\widetilde{X}_{j}^{k}\right)$ is in life expectancy in $j$-th RF region assessed as per the neural network model in accordance with $k$-th scenario impacts exerted by factors, days;

$\tilde{X}_{j}^{k}$ is a vector of initial variables into the neural network model corresponding to the $j$-th RF region according to $k$-th scenario impacts exerted by factors after factor transformation has been completed;

$$
F\left(\tilde{X}_{j}^{0}\right), \tilde{X}_{j}^{0} \text { are values corresponding to }
$$

zero scenario which means all the variables were given actual values determined in a given region.

\footnotetext{
${ }^{11}$ Zaitseva N.V., Onishchenko G.G., Popova A.Yu., Kleyn S.V., Kiryanov D.A., Glukhikh M.V. Social and economic determinants and potential for growth in life expectancy of the population in the Russian Federation taking into account regional differentiation. Health Risk Analysis, 2019, no. 4, pp. 14-29. DOI: 10.21668/health.risk/2019.4.02.eng

${ }^{12}$ Popova A.Yu., N.V. Zaitseva, Onishchenko G.G., Kleyn S.V., Glukhikh M.V., Kamaltdinov M.R. Sanitaryepidemiologic determinants and potential for growth in life expectancy of the population in the Russian Federation. Health Risk Analysis, 2020, no. 1, pp. 4-17. DOI: 10.21668/health.risk/2020.1.01.eng

${ }^{13}$ Russian statistical annual bulletin. 2019: Statistical data collection. Rosstat. Moscow, 2019, 708 p. (in Russian).

${ }^{14}$ RF regions. Socioeconomic parameters. 2019: P32 Statistical data collection. Rosstat. Moscow, 2019, 1204 p. (in Russian).
} 
Each scenario in a numeric experiment involved fixing all the variables except parameters reflecting weather and climatic conditions; values of the latter were sequentially equated with values existing in a given RF region. Overall, we developed and examined 85 scenarios (number of regions).

An RF region with the greatest LE losses was determined in each of 85 models showing climatic conditions which was conditionally considered to be the most «prosperous» in an analyzed scenario: when weather and climatic conditions were applied in the model, their influence resulted in maximum decrease in LE in it thus showing that this region had «better» weather and climatic parameters against model ones regarding losses in life expectancy. This «prosperous» region was used as a reference one in a given scenario and losses in LE caused by weather and climatic model parameters in other RF regions were determined in comparison with it. Losses in life expectancy for each region were assessed as per difference between calculated changes and values obtained for a conditionally «prosperous» region (2):

$$
\delta L E_{j}^{k}=\min _{j}\left(\Delta L E_{j}^{k}\right)-\Delta L E_{j}^{k},
$$

where $\delta L E_{j}^{k}$ is losses in life expectancy in $j$-th RF region under $k$-th scenario impacts exerted by factors, days.

To get ultimate assessment, we averaged all values obtained as per 85 scenarios (3):

$$
\overline{\delta L E_{j}}=1 / K \sum_{k} \delta L E_{j}^{k},
$$

where $\overline{\delta L E_{j}}$ are averaged losses in life expectancy in $j$-th $\mathrm{RF}$ region as per $k$-th scenario impacts exerted by factors, days;

Regional assessments of LE losses were generalized for the country as a whole basing on weighted averaging where resident population number was used as a weight coefficient (4):

$$
\overline{\delta L E_{P \Phi}}=\frac{\sum_{j} N_{j} \overline{\delta L E_{j}}}{\sum_{j} N_{j}},
$$

where $\overline{\delta O \Pi \mathcal{K}_{P \Phi}}$ is average weighted losses in life expectancy in the RF, days;

$N_{j}$ is population number in $j$-th RF region, people.

Cause-and-effect relations between the examined parameters were modeled and subsequent calculations were performed within RStudio medium («neural net» package) with neural networks instruments.

We assessed climate-related losses in life expectancy in RF regions classified as per socioeconomic and sanitary-epidemiologic parameters basing on the results obtained via our previous research which allowed us to distribute RF regions into several clusters according to these determinants ${ }^{9,10}$.

Results and discussion. According to official state statistic data most RF regions (68 to be exact) are located in moderate climatic zones with Atlantic-continental and continental climate with $84.9 \%$ RF population living there. $6 \mathrm{RF}$ regions are located in Arctic and sub-Arctic zones with arctic and sea climate types combined ( $2.4 \%$ RF population). $10 \mathrm{RF}$ regions have mountain climate that is typical for the North Caucasus, Altai, and the Sayan Mountains (8.6 \% RF population) ${ }^{15}$.

We comparatively analyzed the examined weather and climatic factors and revealed that over 2010-2018 average deviations from average long-term temperatures in January and July on average grew by $1.7^{\circ} \mathrm{C}$ in January (from $-1.0^{\circ} \mathrm{C}$ to $3.3^{\circ} \mathrm{C}$ ) and by $1.3{ }^{\circ} \mathrm{C}$ in July (from $-0.7^{\circ} \mathrm{C}$ to $2.3^{\circ} \mathrm{C}$ ), several regions excluded. Deviations exceeded climatic average monthly standard and it confirmed predictions as regards global warming. Besides, there were changes in average deviations from average long-term precipitations (more than $\pm 20.0 \%$ from the standard) that fell in January and July

\footnotetext{
${ }^{15}$ Russian regions. Basin characteristics of the RF regions. 2019: Statistic data collection. Rosstat. Moscow, 2019, 766 p. (in Russian).
} 
in 33 RF regions: the most substantial deviations were registered in January as average deviation from average long-term average monthly value was equal to $13.0 \%$ (from $47.8 \%$ to $146.6 \%$ ); the same deviation in July amounted to $(-1.9 \%)$. We also analyzed absolute temperatures averaged over 2010-2018; the analysis revealed the following RF regions with the warmest weather in January: Crimea $\left(+1.4{ }^{\circ} \mathrm{C}\right)$, Krasnodar region $\left(+0.8^{\circ} \mathrm{C}\right)$, and Adygei Republic $\left(+0.5^{\circ} \mathrm{C}\right)$. Regions with the coldest weather in July were Chukotka $\left(+10.1^{\circ} \mathrm{C}\right)$, the Nenets Autonomous Area $\left(+11.7^{\circ} \mathrm{C}\right)$, and Kamchatka $\left(+13,3^{\circ} \mathrm{C}\right)$. Astrakhan region has the hottest weather in July with average long-term temperature there being equal to $+26.8^{\circ} \mathrm{C}$ in this month.

While building a neural network model based on a set of the examined weather and climatic parameters of the RF regions we managed to select an optimal network structure that consisted of two internal layers containing 8 and 3 neurons accordingly and was characterized with the maximum determination coefficient $R^{2}=0,78$.

We assessed how intensely the examined parameters influenced life expectancy; the assessment revealed that socioeconomic and social-demographic parameters were priority ones as they occupied the first 15 rank places; for example, if there was a $1 \%$ growth in «Working hours per 1 employed on average per 1 week» parameter, LE grew by 6.1 days; a $1 \%$ growth in «A share of employable population, \%» parameter resulted in 5.1 additional days; a $1 \%$ growth in «A share of employable population aged 15-72 with higher education, \%» parameter, 4.8 additional days; etc.

As for weather and climatic conditions, the greatest influence on life expectancy was exerted by «average monthly temperature in July». Thus, on average in the country a $1 \%$ growth in the parameter led to LEB growing by 1.7 days. Apart from this parameter, a $1 \%$ growth in other parameters in July, such as «deviation from average long-term precipitations rate in July», «deviation from average long-term temperature in July», and "average long-term precipitations in July» resulted in calculated LE growth by 0.4 days, 0.18 days, and 0.16 days accordingly. "Average longterm precipitations in January» turned out to be the most significant parameter resulting in LE decrease as $1 \%$ growth in it led to LE reducing by 0.12 days. An increase by $1 \%$ in the remaining analyzed weather and climatic factors in January («average monthly temperature in January», «deviation from average longterm temperature in January», «deviation from average long-term precipitations rate in January») also caused a decrease in life expectancy, excluding «average monthly temperature in January» since growth in the latter resulted in LE growth (Table 1). All these estimations are made for the country on average and do not take regional peculiarities into account. Given that, all obtained results can be applied and interpreted within limits imposed by federal generalization and limits of a neural network model application.

Scenario modeling that took regional parameter values into account allowed us to obtain differential estimations for emergent influence exerted by weather and climatic factors on life expectancy in specific regions. Figure 1 shows results obtained via regional estimates of life expectancy losses caused by impacts exerted by weather and climatic factors and obtained via scenario modeling as per 85 climatic models.

Our study that included 85 weather and climatic scenarios for each RF region allowed revealing that losses in life expectancy caused by climatic factors influence varied substantially in different regions, from -4 days to -349 days (Figure 1).

Spotting out specific clusters on the RF territory as per losses value (Figure 1) clearly demonstrates that they tend to grow in north-eastern direction; it correlates with a well-known phenomenon which is called «northern-eastern gradient of growth in mortality» in scientific literature $[19,20]$. And it should be noted that weather and climatic conditions also change in this direction, so we can tentatively conclude that future warming will probably result in climate becoming milder in most RF regions and, consequently, in certain growth in life expectancy. 
Table 1

Averaged changes in life expectancy of RF population caused by changes in the examined weather and climatic factors given in relevant measurement units (Celsius degrees, millimeters), by $1 \%$

\begin{tabular}{|l|c|c|c|c|}
\hline \multirow{2}{*}{\multicolumn{1}{|c|}{ Parameter }} & \multicolumn{2}{|c|}{ Changes in LE (in days) given: } & \multicolumn{2}{c|}{$\begin{array}{c}\text { Neural network model } \\
\text { application limits, range: }\end{array}$} \\
\cline { 2 - 5 } & $\begin{array}{c}\text { A 1 \% } \\
\text { increase in the } \\
\text { parameter }\end{array}$ & $\begin{array}{c}\text { An increase by 1 meas- } \\
\text { urement unit (Celsius } \\
\text { degrees, millimeters) }\end{array}$ & from & to \\
\hline $\begin{array}{l}\text { Average monthly temperature } \\
\text { in July, }{ }^{\circ} \mathrm{C}\end{array}$ & 1.68 & 8.83 & 7.2 & 29.2 \\
\hline $\begin{array}{l}\text { Average monthly precipitations in } \\
\text { July, mm }\end{array}$ & 0.16 & 0.22 & 3.0 & 319.0 \\
\hline $\begin{array}{l}\text { Deviation from average long-term } \\
\text { temperature in July, }{ }^{\circ} \mathrm{C}\end{array}$ & 0.18 & 16.82 & -4.2 & 5.8 \\
\hline $\begin{array}{l}\text { Deviation from average long-term } \\
\text { precipitation rate in July, \% }\end{array}$ & 0.35 & 0.35 & 4.0 & 359.0 \\
\hline $\begin{array}{l}\text { Average monthly temperature in } \\
\text { January, }{ }^{\circ} \mathrm{C}\end{array}$ & 0.08 & 0.64 & -39.4 & 3.5 \\
\hline $\begin{array}{l}\text { Average monthly precipitations in } \\
\text { January, mm }\end{array}$ & -0.12 & -0.33 & 2.0 & 169.0 \\
\hline $\begin{array}{l}\text { Deviation from average long-term } \\
\text { temperature in January, }{ }^{\circ} \mathrm{C}\end{array}$ & -0.04 & -2.8 & -7.4 & 8.9 \\
\hline $\begin{array}{l}\text { Deviation from average long-term } \\
\text { precipitation rate in January, \% }\end{array}$ & -0.08 & -0.07 & 7.0 & 350.0 \\
\hline
\end{tabular}

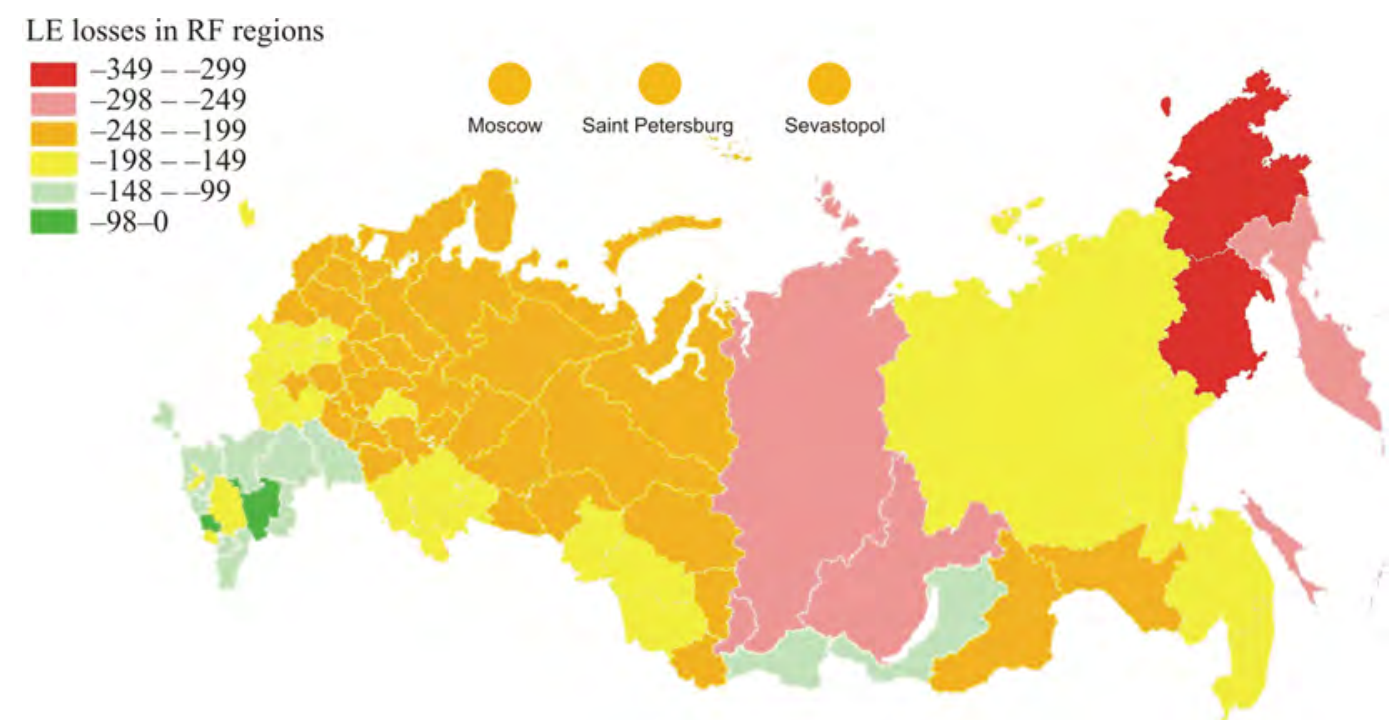

Figure 1. Averaged losses in life expectancy in RF regions caused by influence exerted by weather and climatic factors and obtained basing on 85 climatic models, days

Averaged weighting of all the obtained results revealed that overall LE losses due to weather and climatic factors in the RF amounted to 191.7 days. Basic factors that determine this value include average monthly temperature in July (approximately $76 \%$ ), de- viation from average long-term precipitation rate in July (15.8\%), and deviation from average long-term temperature in July $(8.1 \%)$.

We also analyzed averaging results as per regions located in different weather and climatic zones; the results are given in Figure 2. 


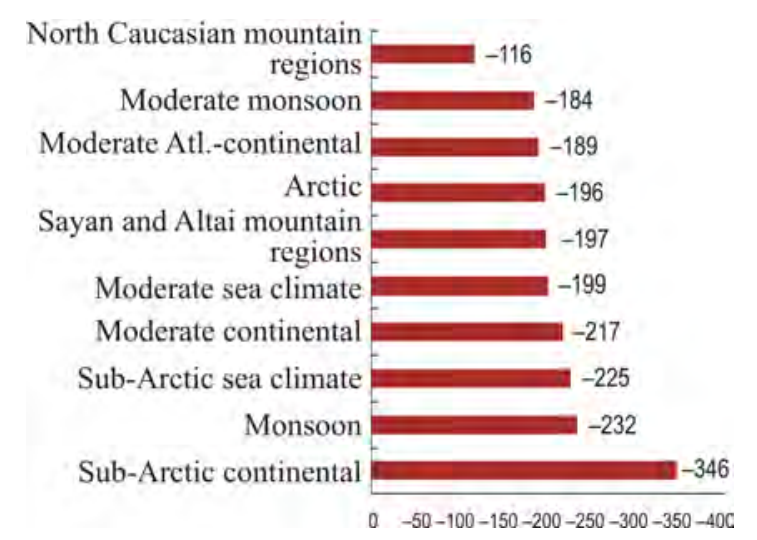

Figure 2. Averaged LE losses caused by weather and climatic factors taken as per average weighted value according to population number in RF regions distributed into groups as per climatic zone they are located in, days

This analysis allowed detecting certain peculiarities that occurred due to impacts exerted by a set of parameters being specific and variable.

Variability and emergence of impacts exerted by climatic factors had its influence on LE losses associated with these factors in $\mathrm{RF}$ regions located in different climatic zones (latitude zoning). Thus, LE losses in regions located in moderate zones with Atlanticcontinental climate (50 regions) on average amounted to -189 days (varying from -244 in
Karelia to -4 days in Kalmyk Republic) (Figure 3). Variability of climate-associated LE losses is caused by aggregated impacts exerted by multidirectional climatic factors but to a greater extent it is determined by temperatures in January (varying from $-16.7^{\circ} \mathrm{C}$ to $+1.6{ }^{\circ} \mathrm{C}$; average value in the zone is $\left(-8.5^{\circ} \mathrm{C}\right)$; in the RF, $\left.\left(-12.0{ }^{\circ} \mathrm{C}\right)\right)$ and July (varying from $+11.7^{\circ} \mathrm{C}$ to $+26.8{ }^{\circ} \mathrm{C}$; average value in the zone is $\left(+20.2{ }^{\circ} \mathrm{C}\right)$; in the $\mathrm{RF}$, $\left(+19.2^{\circ} \mathrm{C}\right)$ ), precipitations in January (varying from $16.3 \mathrm{~mm}$ to $92.1 \mathrm{~mm}$; average zone value is $43.7 \mathrm{~mm}$; in the RF, $35.7 \mathrm{Mm}$ ) and July (varying from $18.6 \mathrm{~mm}$ to $93.6 \mathrm{~mm}$; average value in the zone is $66.9 \mathrm{~mm}$; in the RF, $72.4 \mathrm{~mm}$ ).

Climate-associated LE losses in zones with moderate continental climate (12 RF regions) amounted to -217 days on average (the range was from -283 days in Krasnoyarsk region to -133 days in Buryatia). LE losses in this climatic zone are due to comparatively low temperatures in January $\left(-20.6{ }^{\circ} \mathrm{C}\right.$; in the $\left.\mathrm{RF},-12.0{ }^{\circ} \mathrm{C}\right)$ and July $(+17.5$; in the $\mathrm{RF}$, $\left.+19.2{ }^{\circ} \mathrm{C}\right)$; at the same time precipitations in January are comparatively lower $(18.6 \mathrm{~mm}$; in the RF, $35.7 \mathrm{~mm}$ ), and in July, comparatively higher $(78.4 \mathrm{~mm}$; in the RF, $72.4 \mathrm{~mm}$ ) than on average in the country.

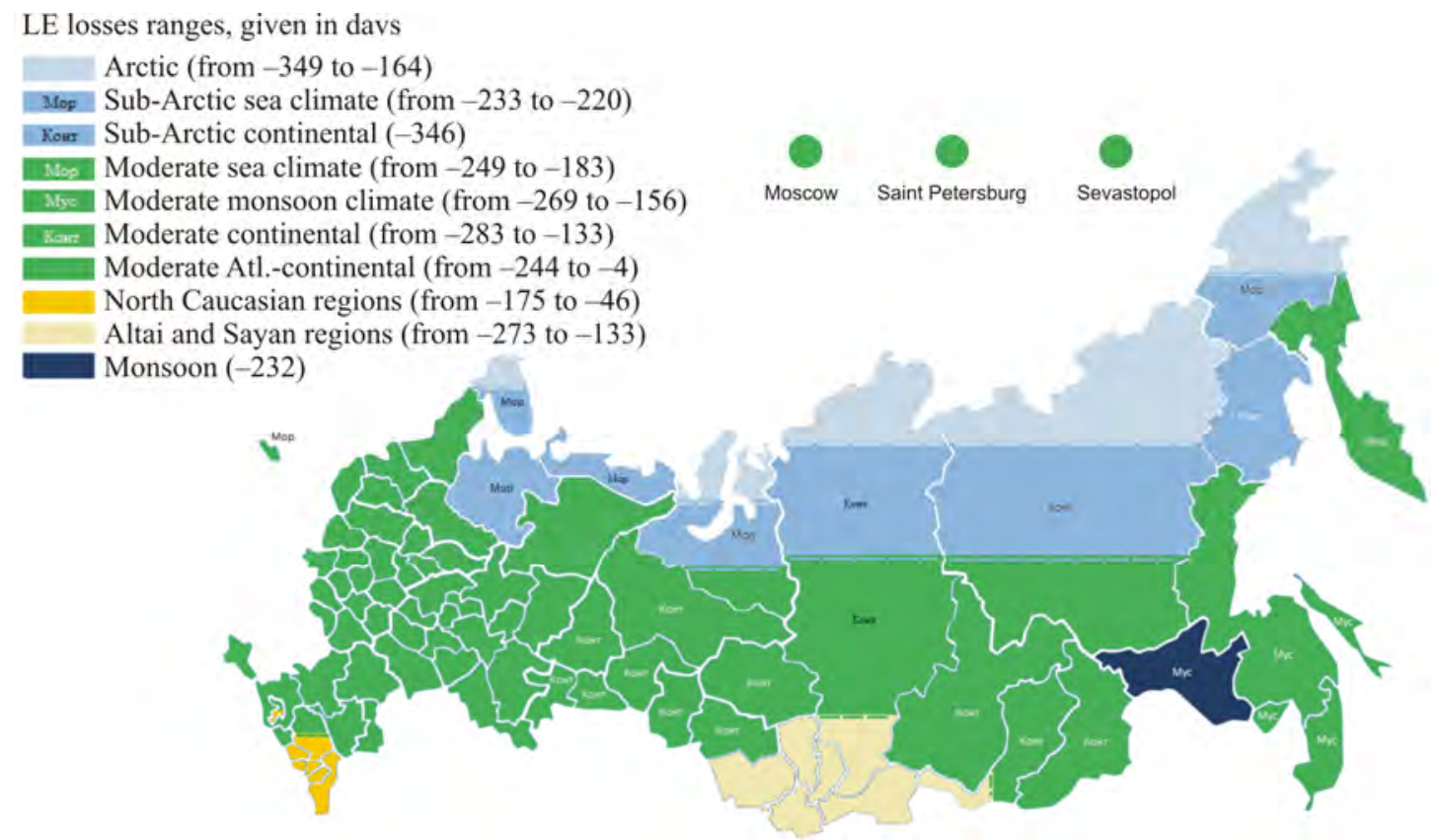

Figure 3. A map showing climatic zones and climate types in RF regions and occurring climate-associated LE losses, days (if a regions has several climatic zones they are shaded with a respective color) 
The greatest climate-associated LE losses occur in Magadan region located in a subArctic zone with continental climate; LE losses there amounted to -346 days (Figures 1 and 3). Substantial LE losses in the region are caused by low temperatures in January $\left(-27.2{ }^{\circ} \mathrm{C}\right.$; in the RF, $\left.-12.0^{\circ} \mathrm{C}\right)$ and July $\left(13.9{ }^{\circ} \mathrm{C}\right.$; in the RF, $19.2^{\circ} \mathrm{C}$ ) as well as relatively low precipitations in July (61.8 mm; in the RF, $72.4 \mathrm{~mm})$.

The smallest LE losses caused by weather and climatic factors are detected in RF regions located on territories with mountain North Caucasian climate (5 RF regions); average losses there amounted to -119 days with their range varying from -175 in North Ossetia to -46 days in Kabardino-Balkaria (Figures 1 and 3). Low LE losses in regions located in this climatic zone are mostly due to higher temperatures in January $\left(-1.87^{\circ} \mathrm{C}\right.$; in the RF $\left.\left(-12.0^{\circ} \mathrm{C}\right)\right)$ and in July $\left(+22.9^{\circ} \mathrm{C}\right.$; in the RF, $\left.+19.2^{\circ} \mathrm{C}\right)$ as well as lower precipitation in January $(26.9 \mathrm{~mm}$; in the $\mathrm{RF}, 35.7 \mathrm{~mm}$ ).

These data indicate that climate-associated losses in life expectancy are substantial in most $\mathrm{RF}$ regions and it requires developing and implementing compensatory activities, including those aimed at improving socioeconomic parameters and providing support for population living in regions located in zones with adverse weather and climatic conditions.

Comparative analysis of LE losses in different climatic zones revealed authentic discrepancies (as per Mann-Whitney test) between regions located in North Caucasian mountain zones and regions located in moderate zones with Atlantic-continental climate $(p=0.002)$ and with continental climate $(p=0.003)$.

Results obtained via the analysis allowed making a hypothesis on probable mutual or one-directional influence exerted by socioeconomic, sanitary-epidemiologic, and weather and climatic factors. To prove it, we performed preliminary calculations of average LE losses for regions distributed into specific groups (clusters) as per socioeconomic and sanitary-epidemiologic parameters described in our previous works ${ }^{9,10}$.

We comparatively analyzed LE losses caused by weather and climatic factors in clus- ters with different socioeconomic situation in RF regions. The analysis revealed that the greatest LE losses occurred in the $1^{\text {st }}$ cluster that included 2 RF regions. Regions included into this cluster are located in an Arctic zone and a zone with moderate Atlantic-continental climate. Average climatic-associated LE losses in the cluster amounted to -236 days (The Yamal-Nenets Autonomous Area, -237 days; the Nenets Autonomous Area, -164 days). Certain economic parameters were high in the cluster including investments into capital assets and gross regional product per capita. But at the same time criminal rate, alcohol consumption, and a share of dilapidated housing were also high in the cluster and it could potentiate negative impacts exerted by weather and climatic factors and created additional risks of greater LE losses. Thus, the cluster included regions that were among those with the lowest temperatures in July $\left(12.5^{\circ} \mathrm{C}\right.$; in the $\left.\mathrm{RF}, 19.2^{\circ} \mathrm{C}\right)$ and the lowest precipitations in July (37.1 mm; in the RF, $72.4 \mathrm{~mm}$ ) as well as with comparatively more significant deviation from average long-term temperature in July $\left(1.5^{\circ} \mathrm{C}\right.$; in the RF, $\left.1.1^{\circ} \mathrm{C}\right)$.

The second cluster occupies the $2^{\text {nd }}$ rank place following the descending order in climate-associated LE losses. Economic parameters are relatively high there, unemployment rate is low, and public healthcare is qualitative; but at the same time, alcohol sales per capita, divorce rate, and crime rate are rather high. Averaged weighted LE losses amounted to -208 days (the range varied from -349 days in Chukotka to -164 in Yakutia). The cluster includes 6 RF regions located in zones with Arctic, sub-Arctic continental, moderate Atlanticcontinental, and continental climate. Climateassociated LE losses in these regions are caused by relatively low temperatures in January (on average $\left(-21.5^{\circ} \mathrm{C}\right)$; in the $\mathrm{RF}\left(-12.0^{\circ} \mathrm{C}\right)$ ) and July $\left(14.5^{\circ} \mathrm{C}\right.$; in the RF $\left.19.2^{\circ} \mathrm{C}\right)$, lower precipitations in July $(63.3 \mathrm{~mm})$ than on average in the country $(72.4 \mathrm{~mm})$, and lower deviation from average long-term temperature in July $\left(0.9^{\circ} \mathrm{C}\right.$; in the RF, $\left.1.1^{\circ} \mathrm{C}\right)$.

Regions included in the $3^{\text {rd }}$ cluster had the following specific features: most analyzed so- 
cioeconomic parameters there corresponded to average country levels; registered unemployment was low; consumption of basic food products was close to recommended levels; high divorce and crime rates; high share of population older than employable age $(25.5 \%)$. Average LE losses in these regions amounted to -203 days with the range varying from -283 days (Krasnoyarsk region) to -137 days (Krasnodar region). Regions included into this cluster (31 overall) are located in zones with moderate Atlantic-continental, continental, and sea climate and tend to have lower temperatures in July (on average $18.6{ }^{\circ} \mathrm{C}$; in the RF, $\left.19.2{ }^{\circ} \mathrm{C}\right)$ and January $\left(-12.7^{\circ} \mathrm{C}\right.$; in the RF $\left(-12.0{ }^{\circ} \mathrm{C}\right)$, higher precipitations in January (37.2 $\mathrm{mm}$; in the RF, $35.7 \mathrm{~mm}$ ), and greater deviation from average long-term precipitations rate in July ( $100.4 \%$; in the RF, $98.0 \%)$.

The $4^{\text {th }}$ cluster turned out to have the lowest LE losses due to weather and climatic factor with average cluster value being -175 days; it varied from -273 days (Khakassia) to -4 (Kalmyk Republic). Socioeconomic parameters in the cluster include low crime rate, low divorce rate, low share of dilapidated housing, and the lowest alcohol sales per capita among all clusters. But still, some economic parameters such as share of housing equipped with centralized water supply, sewage, and heating and public healthcare quality are also rather low. Regions included into this cluster are located in zones with moderate Atlantic-continental climate and continental climate as well as in zones with North Caucasian mountain climate, Altai and Sayan mountain climate. Diverse climatic conditions in the region caused variability in climate-associated LE losses. Climate-associated LE losses were relatively low in the cluster due to the following factors: relatively low precipitations $(71.2 \mathrm{~mm}$; in the RF, $73.3 \mathrm{MM})$, more substantial deviation from average long-term precipitation rate in January $(118.2 \%$; in the RF, $116.8 \%$ ); factors that led to growth in LE included relatively high temperatures in January $\left(-10.0{ }^{\circ} \mathrm{C}\right.$; in the RF, $\left.\left(-11.2^{\circ} \mathrm{C}\right)\right)$ and July $\left(+20.4{ }^{\circ} \mathrm{C}\right.$; in the RF, $\left.+19.7^{\circ} \mathrm{C}\right)$.

Our comparison between clusters that were determined basing on socioeconomic dif- ferentiation of RF regions allowed us to reveal authentic discrepancies (as per Mann-Whitney test) in climate-associated LE losses between the $2^{\text {nd }}$ and the $4^{\text {th }}$ cluster $(p=0.01)$, as well as between the $3^{\text {rd }}$ and the $4^{\text {th }}$ cluster $(p=0.006)$ (Figure $4 a)$.

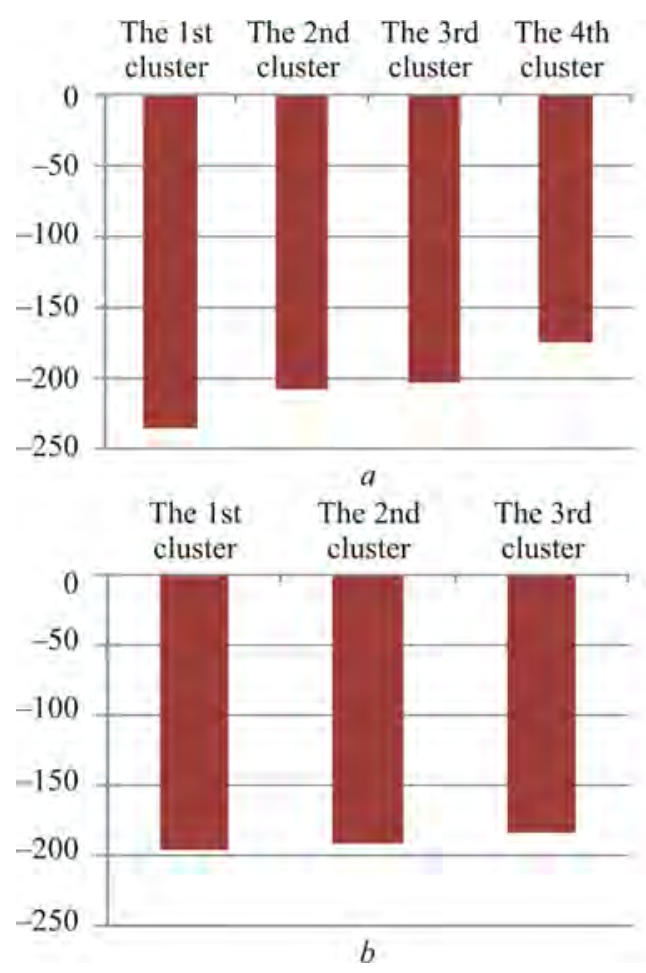

Figure 4. Averaged LE losses caused by weather and climatic factors given in averaged weighted values as per population number in RF regions distributed into several clusters with different socioeconomic (a) and sanitary-epidemiologic (b) parameters, days

We comparatively analyzed LE losses caused by weather and climatic factors in clusters with different sanitary-epidemiologic situation in regions included into them; the analysis didn't reveal any significant discrepancies. Climate-associated LE losses averaged weighted as per population number amounted to -196 days in the $1^{\text {st }}$ cluster; -191 days and 184 days in the $2^{\text {nd }}$ and the $3^{\text {rd }}$ clusters accordingly (Figure $4 \mathrm{~b})^{10}$. The results indicate that weather and climatic parameters exert the same impacts (LE losses) on regions with different sanitary-epidemiologic situation and they are similar to average country level.

Accomplished preliminary analysis allowed revealing combined emergent and variable influence exerted by weather and climatic conditions and socioeconomic determinants on 
LE: the phenomenon requires more profound examining and assessing. Basing on the results obtained via the present research we can only conclude that effects produced by these factors can either mutually enhance or weaken each other and they should be taken into account when planning and implementing programs aimed at improving socio-demographic situation in RF regions bearing regional differentiation in mind.

Given that we can't manage weather and climatic factors and our ability to adapt to them is rather limited as well as a significant contribution made by them into changes in LE, we can conclude that these factors should be given special attention and taken into account when implementing programs aimed at improving socio-demographic situation in RF regions.

Conclusions. Basing on the accomplished research work we can conclude the following:

1. Over the last decades climate changed in many RF regions, especially in arctic and subarctic zones and in the eastern part of the country as well; as per the last estimates, changes occurred at a rate 2.5 times higher than on average in the world. Ground air temperatures and precipitations underwent the greatest changes (average deviations from average long-term temperatures in July over 2010-2018 amounted to $+1.2{ }^{\circ} \mathrm{C}$, in January $+1.5^{\circ} \mathrm{C}$; the same deviations in precipitations quantity amounted to $-1.9 \%$ in July and $+13.0 \%$ in January).

2. Global processes related to climate change indicate that weather and climatic conditions tend to become milder in most RF regions; in its turn, it can result in living conditions becoming more comfortable and consequent health improvement and longer life expectancy in these regions. Our research on a system of cause-and effect relations between socioeconomic, sanitary-epidemiologic, and weather and climatic indicates that it is necessary to study multidirectional consequences of global warming in greater detail. The research results revealed that provided that there are mo drastic climatic changes life expectancy is likely to grow in RF regions in case average temperature increases. Thus, regularities ob- tained for the country in general show that an increase in average temperature in July results in LE growing by 8.83 days and by 0.64 days in case in increases in January. These results are limited by a model definition range: from $+7.2{ }^{\circ} \mathrm{C}$ to $+29.2{ }^{\circ} \mathrm{C}$ in July; from $-39.4{ }^{\circ} \mathrm{C}$ to $+3.5{ }^{\circ} \mathrm{C}$ in January; they do not take extreme changes in climatic and weather conditions into account.

3. Most people in the RF live in climatic zones with conditions that are far from being optimal; it causes losses in life expectancy associated with weather and climatic factors. Our estimations revealed that climate-associated LE losses amounted to -191.7 in the RF on average but losses in regions varied from -4 days (in Kalmyk Republic) to -349 days (in Chukotka).

Basic factors that cause LE losses include socioeconomic conditions as they occupy 15 first rank places among all the parameters. Average temperature in July exerts the most significant impacts as it accounts for approximately $76 \%$ LE losses on average in the country.

4. We comparatively analyzed LE losses caused by emergence of weather and climatic factors as per climatic zones. The analysis revealed that climate-associated LE losses in regions located in the North Caucasian mountain zones were authentically lower than in regions located in moderate zones with Atlanticcontinental and continental climate (by 1.6 and 1.8 times accordingly). Thus, LE losses varied from -283 to -4 days in zones with moderate climate where most RF population lived $(84.9 \%)$; they were on average caused by high precipitations in January $(38.4 \mathrm{~mm}$; in the RF, $35.7 \mathrm{~mm}$ ) and deviations from average longterm temperatures $\left(1.6{ }^{\circ} \mathrm{C}\right.$; in the RF, $\left.1.5^{\circ} \mathrm{C}\right)$ and precipitations $(115.0 \mathrm{~mm}$; in the $R F$, $113.4 \mathrm{~mm}$ ) in January. LE losses varied from -175 days to -46 days in the North Caucasian mountain climatic zones where $4.5 \%$ RF population lived; these losses were determined by on average relatively higher temperature in January $\left(-1.87^{\circ} \mathrm{C}\right.$; in the $\left.\mathrm{RF},-12.0^{\circ} \mathrm{C}\right)$ and July $\left(+22.9{ }^{\circ} \mathrm{C}\right.$; in the RF, $\left.+19.2^{\circ} \mathrm{C}\right)$ as well as lower precipitations in January $(26.9 \mathrm{~mm}$; in the RF, $35.7 \mathrm{~mm}$ ). 
5. The research allowed revealing effects produced by combined exposure to weatherclimatic and socioeconomic factors and it requires more profound examination in future research works.

6. It is extremely important to implement national and regional programs aimed at prolonging life expectancy as it will improve demographic situation in the country; given that, impacts exerted by unmanageable factors, including weather and climatic ones, should be taken into account as significant components in achieving targets fixed within such programs.

In future works the authors plan to continue studying combined, share, and mutual impacts exerted by weather and climatic, socioeconomic, and sanitary-epidemiologic determinants on population health in the Russian Federation.

Funding. The research was not granted any sponsor support.

Conflict of interests. The authors declare there is no any conflict of interests.

\section{References}

1. Climate Change. United Nations, 2020. Available at: https://www.un.org/ru/sections/issuesdepth/climate-change/index.html (30.09.2020) (in Russian).

2. Global Warming of $1.5^{\circ} \mathrm{C}$. Intergovernmental Panel on Climate Change (IPCC), 2018. Available at: https://www.ipcc.ch/sr15/ (30.09.2020).

3. Kuz'min V. Rossiya stala polnopravnym uchastnikom Parizhskogo soglasheniya po klimatu [Russia has become a full-fledged member of Paris climate agreement]. Rossiiskaya gazeta, 2019. Available at: https://rg.ru/2019/09/23/rossiia-stala-polnopravnym-uchastnikom-parizhskogo-soglasheniia-poklimatu.html (30.09.2020) (in Russian).

4. Climate change and health. World health organization, 2018. Available at: https://www.who.int/ $\mathrm{ru} /$ news-room/fact-sheets/detail/climate-change-and-health (30.09.2020) (in Russian).

5. Patz J.A., Frumkin H., Holloway T., Vimont D.J., Haines A. Climate change: challenges and opportunities for global health. JAMA, 2014, vol. 312, no. 15, pp. 1565-1580. DOI: 10.1001/jama.2014.13186

6. Achebak H., Devolder D., Ballester J. Trends in temperature-related age-specific and sexspecific mortality from cardiovascular diseases in Spain: a national time-series analysis. Lancet Planet Health, 2019, vol. 3, no. 7, pp. e297-306. DOI: 10.1016/S2542-5196(19)30090-7

7. Medina-Ramon M., Schwartz J. Temperature, temperature extremes, and mortality: a study of acclimatization and effect modification in 50 US cities. Occupational and Environmental Medicine, 2007, vol. 64, no. 12, pp. 827-833. DOI: 10.1136/oem.2007.033175

8. Zhang L., Ye T., Zhou M., Wang C., Yin P., Hou B. Mortality effects of heat waves vary by age and area: a multi-area study in China. Environmental Health, 2018, vol. 17, no. 1, pp. 54. DOI: 10.1186/s12940-018-0398-6

9. Li G., Huang J., Xu G., Pan X., Qian X., Xu J., Zhao Y., Zhang T. [et al.]. Temporal variation in associations between temperature and years of life lost in a southern China city with typical subtropical climate. Scientific Reports, 2017, vol. 7, no. 1, pp. 4650. DOI: 10.1038/s41598-017-04945-6

10. Liu J., Ma Y., Wang Y., Li S., Liu S., He X., Li L., Guo L. [et al.]. The impact of cold and heat on years of life lost in a northwestern Chinese city with temperate continental climate. Environmental Research and Public Health, 2019, vol. 16, no. 19, pp. 3529. DOI: 10.3390/ijerph16193529

11. Doherty R.M., Heal M.R. O'Connor F.M. Climate change impacts on human health over Europe through its effect on air quality. Environmental Health, 2017, vol. 16, no. 1, pp. 118. DOI: 10.1186/s12940-017-0325-2

12. Orru H., Ebi K. L., Forsberg B. The interplay of climate change and air pollution on health. Current environmental health reports, 2017, vol. 4, no. 4, pp. 504-513. DOI: 10.1007/s40572-017-0168-6

13. Finch C.E., Beltran-Sanchez H., Crimmins E.M. Uneven futures of human lifespans: Reckonings from Gompertz mortality rates, climate change, and air pollution. Gerontology, 2014, vol. 60, no. 2 , pp. $183-188$. DOI: $10.1159 / 000357672$

14. Chen K., Fiore A.M., Chen R., Jiang L., Jones B., Schneider A., Peters A., Bi J., Kan H., P.L. Kinney Future ozone-related acute excess mortality under climate and population change sce- 
narios in China: A modeling study. PLOS Medicine, 2018, vol. 15, no. 7, pp. e1002598. DOI: 10.1371/journal.pmed.1002598

15. Hauer M.E., Santos-Lozada A.R. Inaction on climate change projected to reduce European life expectancy. Population research and policy review, 2019, no. 13, pp. 14. DOI: 10.1007/s11113-020-09584-w

16. Revich B.A., Shaposhnikov D.A. Influence features of cold and heat waves to the population mortality - the city with sharply continental climate Sibirskoe meditsinskoe obozrenie, 2017, vol. 104, no. 2, pp. 84-90 (in Russian). DOI: 10.20333/2500136-2017-2-84-90

17. Revich B.A., Shaposhnikov D.A., Anisimov O.A., Belolutskaya M.A. Heat waves and cold spells in three arctic and subarctic cities as mortality risk factors. Gigiena i sanitariya, 2018, vol. 97, no. 9, pp. 791-798 (in Russian). DOI: 10.18821/0016-9900-2018-97-9-791-798

18. Riski i vygody dlya Rossiiskoi Federatsii ot global'nogo izmeneniya klimata [Global climatic change: risks and benefits for the Russian Federation]. Rosgidromet, 2014. Available at: http://www.meteorf.ru/special/press/releases/8435/ (30.09.2020) (in Russian).

19. Slyusar' K.S. Osobennosti protekaniya demograficheskikh protsessov v Altaiskom krae [Peculiarities of demographic processes in Altai region]. Aktual'nye voprosy funktsionirovaniya ekonomiki Altaiskogo kraya, 2010, no. 2, pp. 64-74 (in Russian).

20. Kvasha E.A., Khar'kova T.L. Regional peculiarities of mortality in Russia at the beginning of XXI century from the standpoint of incompleteness of epidemiological transition. Voprosy statistiki, 2010, no. 7, pp. 29-41 (in Russian).

Zaitseva N.V., Kleyn S.V., Kiryanov D.A., Glukhikh M.V., Kamaltdinov M.R. Emergence and variability of influence exerted by weather and climatic factors on life expectancy in the russian federation taking into account differentiation of rf regions as per socioeconomic and sanitary-epidemiologic determinants. Health Risk Analysis, 2020, no. 4, pp. 63-76. DOI: 10.21668/health.risk/2020.4.07.eng

Received: 02.09.2020

Accepted: 03.12.2020

Published: 30.12.2020 